\title{
Inter- and intra-annual trends and status indicators of nektobenthic elasmobranchs off the Balearic Islands (northwestern Mediterranean)
}

\author{
BEATRIZ GUIJARRO, ANTONI QUETGLAS, JOAN MORANTA, FRANCESC ORDINES, \\ MARIA VALLS, NATALIA GONZÁLEZ and ENRIC MASSUTÍ \\ Instituto Español de Oceanografía, Centre Oceanogràfic de les Balears, Moll de Ponent s/n, 07015 Palma, Spain. \\ E-mail: beatriz@ba.ieo.es
}

SUMMARY: We assessed the elasmobranch communities exploited by the bottom trawl fishery off the Balearic Islands (northwestern Mediterranean) by analysing two time series containing information with different levels of detail: 1) a longterm series containing the abundance indices of the whole elasmobranch community landed from 1965 to 2009; and 2) a shorter time series from 2000 to 2009 from two different data sources (daily sales records: 2000-2009; bottom trawl surveys: 2001-2009), with information that allowed the shelf and slope to be analysed separately and different community parameters and abundance indices to be studied. Temporal trends of all these variables were used as ecological status indicators and tested with generalized additive models and analysis of variance. They were finally summarised using the Traffic Light methodology. The long-term series showed two marked trends, an inter-annual decreasing trend that would be a consequence of the large increase in fishing effort, and an intra-annual trend with a clear peak in May in accordance with the seasonal biological cycle of these species. However, data from the last ten years revealed differences between the shelf and slope, as some parameters increased significantly over time on the shelf but did not follow any trend on the slope. The Traffic Light methodology captured these differences well, demonstrating its usefulness for interpreting ecological transitions at a glance.

Keywords: elasmobranchs, assessment, Traffic Light method, indicators, fishing effort, Balearic Islands.

RESUMEN: TENDENCIAS INTER E INTRA-ANUALES E INDICADORES DEL ESTADO DE LAS POBLACIONES DE ELASMOBRANQUIOS NECTOBENTÓNICOS DE LAS Islas BALEARES (MEDITERRÁNEO NORDOCCIDENTAL). - Se han evaluado las poblaciones de elasmobranquios explotadas por la pesca de arrastre de las Islas Baleares (Mediterráneo noroccidental) analizando dos series temporales con información a distinto nivel de detalle: 1) una serie larga que contiene únicamente el índice de abundancia de toda la población de elasmobranquios desembarcada entre 1965 y 2009 y 2) una serie corta a lo largo de la primera década del siglo XXI proveniente de dos fuentes de datos diferentes (hojas de venta diarias: 2000-2009; campañas de arrastre de fondo: 2001-2009), que permitieron el análisis, para la plataforma y el talud por separado, de diferentes parámetros de la comunidad además de índices de abundancia. Las tendencias temporales de todas estas variables se usaron como indicadores ecológicos de estado y se testaron aplicando modelos generales aditivos y análisis de la varianza y finalmente se han resumido usando la metodología de los Semáforos. La serie larga mostró dos señales claras, un decrecimiento interanual que podría ser consecuencia del importante incremento del esfuerzo pesquero, y una tendencia intra-anual con un claro pico en mayo, relacionado con el ciclo biológico estacional de estas especies. Así y todo, los datos del primer decenio del siglo XXI revelaron diferencias entre la plataforma y el talud, porque algunos parámetros aumentaron significativamente con el tiempo en el primer caso, pero no siguieron ninguna tendencia en el segundo. Estas diferencias quedaron bien reflejadas en los Semáforos, demostrando su utilidad en reflejar las transiciones ecológicas.

Palabras clave: elasmobramquios, evaluación, metodología de los semáforos, indicadores, esfuerzo pesquero, Islas Baleares.

\section{INTRODUCTION}

In recent years fishery assessment and management have progressively changed from the traditional mono- specific approach to a new ecosystem approach that takes into account the complexity of ecosystems and their natural and anthropogenic variations (Browman and Stergiou 2004). However, the high complexity 
of this new approach means that practical procedures need to be used, such as analysing smaller components of the system that can reflect environmental impacts (Rogers et al. 1999). In this sense, elasmobranchs are considered indicators of fishing pressure owing to the high vulnerability and low recovery capacity of their populations (Stevens et al. 2000).

In spite of this, little research has been carried out on this group, and the lack of accurate species-specific landings data in many European fisheries and the paucity of biological data have restricted population assessments (Ellis et al. 2005). In the Mediterranean, there are numerous studies on demersal fish assemblages, but only recently have some papers focussed on the elasmobranch communities (e.g. Bertrand et al. 2000, Capapé et al. 2000, Relini et al. 2000, Massutí and Moranta 2003, Gouraguine et al. 2011, Ordines et al. 2011).

The practical implementation of an ecosystem approach to fisheries means that ecological indicators need to be used (Jennings 2005). These have to be summarised in a manageable way in order to express the complexity inherent to the ecosystems and provide evidence of environmental impacts (Rochet and Trenkel 2003). A procedure that is currently popular is the Traffic Light (TL) approach (Caddy 2002), designed to be a precautionary fisheries management framework in data poor situations (Caddy 1998, 1999), but which can be extended to other scenarios independently of the amount of available data (Halliday et al. 2001). TL displays time series indicators in a way that helps to give a clear visual impression of the likely transitions and relationships between the indicators (Caddy et al. 2005). This methodology has been applied for single- and multi-species assessments both in the Atlantic and the Mediterranean (Caddy et al. 2005, DFO 2005, Ceriola et al. 2007, 2008, Guijarro et al. 2011) and tends to be more precautionary than traditional stock assessment methods (Koeller et al. 2000).

The Balearic Islands (northwestern Mediterranean) has a long history of bottom trawl fishing, with a relatively small bottom trawl fleet performing daily fishing trips (Palmer et al. 2009). In these trips, vessels use four different fishing tactics associated with the shallow and deep continental shelf, and the upper and middle continental slope (Guijarro and Massutí 2006, Ordines et al. 2006). The main target species in these grounds are striped red mullet (Mullus surmuletus), European hake (Merluccius merluccius), Norway lobster (Nephrops norvegicus) and red shrimp (Aristeus antennatus) respectively. Shark species are an important bycatch of this fleet, and even reach proportions similar to the target species on the continental shelf (Carbonell et al. 2003). Moreover, the contribution of skates and rays to the assemblages is higher than in nearby areas like the Algerian coast (Ordines et al. 2011). In fact, the diversity of demersal elasmobranchs in the Balearic Islands and in other insular Mediterranean areas is higher than in adjacent waters off the mainland (Massutí and Moranta 2003).
The objective of this paper was to assess the elasmobranch communities in the fishing grounds exploited by the bottom trawl fishery in the Balearic Islands, by analysing temporal variations of community abundance at different time scales (intra- and inter-annual) using different sources of information (experimental and commercial data).

\section{MATERIALS AND METHODS}

This work, whose study area covers the waters around the Balearic Islands (northwestern Mediterranean; Fig. 1), was performed by analysing two time series containing information with different levels of detail. The first one was a long-term historical time series (HTS) containing exclusively the monthly catch per unit effort (CPUEs; $g \cdot H^{-1}$ ) of elasmobranchs from the bottom trawling fleet of Mallorca, the largest island of the Balearic Archipelago, between 1965 and 2009. The second one was a shorter time series containing information from two different sources and which allowed the shelf and slope to be analysed separately. This time series contained 1) daily sales records (DSB) from the trawl fleet of Mallorca between 2000 and 2009, from which the daily CPUE of elasmobranchs was obtained for each individual boat throughout the year $\left(\mathrm{kg}\right.$ day $^{-1}$ boat $^{-1}$ ), and 2) annual bottom trawl surveys (BTS) from 2001 to 2009 , performed during late spring and early summer following the international MEDITS protocol (Bertrand et al. 2002). In these surveys, the total biomass $\left(\mathrm{kg} \mathrm{km}^{-2}\right)$, total abundance $\left(\mathrm{n} \mathrm{km}^{-2}\right)$, species richness (S), Shannon's diversity index ( $\left.\mathrm{H}^{\prime}\right)$ and mean fish weight (MFW; g) of elasmobranchs taken between 45 and $765 \mathrm{~m}$ depth were analysed.

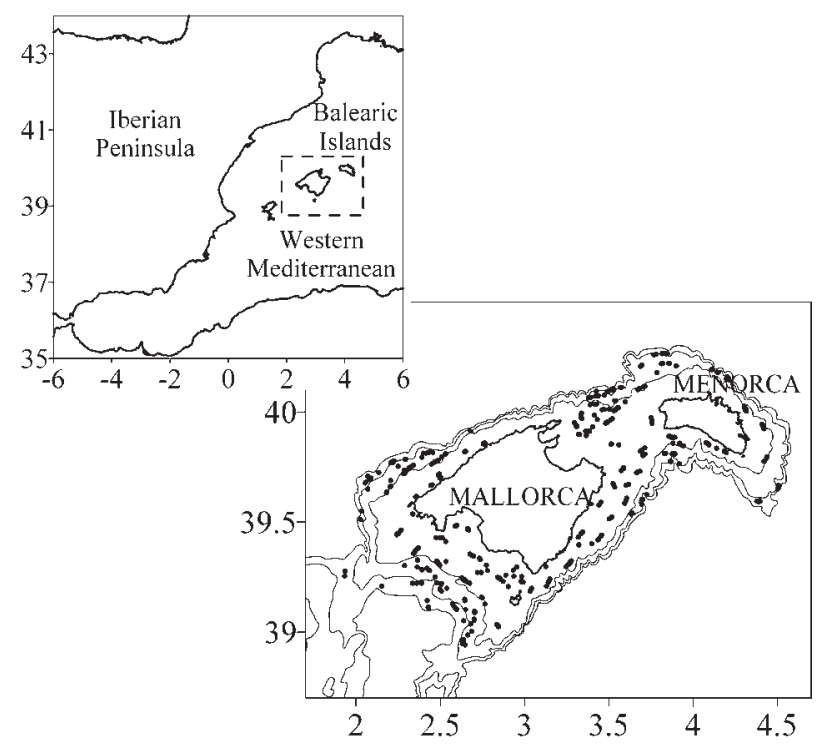

FIG. 1. - Map of the study area showing the sampling stations during the experimental bottom trawl surveys carried out in the fishing grounds of the bottom trawl fleet operating in the area. The 200,600 and 800 isobaths are also shown. 
TABLE 1. - Biomass percentage of elasmobranch species caught from the different sources of data (HTS: long term historical time series; DSB: daily sale bills from the bottom trawl fleet; BTS: annual bottom trawl surveys) around the Balearic Islands. +: percentage lower than $1 \%$.

\begin{tabular}{|c|c|c|c|c|c|c|}
\hline & & \multirow[t]{2}{*}{ HTS } & \multicolumn{2}{|c|}{ DSB } & \multicolumn{2}{|c|}{ BTS } \\
\hline & & & Shelf & Slope & Shelf & Slope \\
\hline Hexanchidae & Hexanchus griseus & & & 22 & & \\
\hline Squalidae & Squalus blainvillei & & 1 & + & 11 & 2 \\
\hline Centrophoridae & Centrophorus granulosus & & + & 3 & & 2 \\
\hline Etmopteridae & Etmopterus spinax & & & & & 3 \\
\hline Dalatiidae & Dalatias licha & & & & & + \\
\hline \multirow[t]{3}{*}{ Scyliorhinidae } & Galeus melastomus & 40 & + & 50 & + & 69 \\
\hline & Scyliorhinus canicula & 10 & 47 & 11 & 43 & 13 \\
\hline & Scyliorhinus stellaris & & & & + & \\
\hline \multirow[t]{2}{*}{ Triakidae } & Mustelus asterias & & & & + & \\
\hline & Mustelus mustelus & & 1 & 2 & + & \\
\hline Torpedinidae & Torpedo marmorata & & & & + & + \\
\hline \multirow{11}{*}{ Rajidae } & Dipturus oxyrinchus & & + & 3 & 1 & 4 \\
\hline & Leucoraja circularis & & & & + & 1 \\
\hline & Leucoraja fullonica & & & & & + \\
\hline & Leисогаја nаevиs & & & & 2 & + \\
\hline & Raja asterias & & & & + & \\
\hline & Raja brachyura & & & & + & + \\
\hline & Raja clavata & 50 & 50 & 10 & 17 & 5 \\
\hline & Raja miraletus & & & & 2 & + \\
\hline & Raja polystigma & & & & 3 & + \\
\hline & Raja radula & & & & 4 & \\
\hline & Rostroraja alba & & & & + & \\
\hline \multirow[t]{2}{*}{ Dasyatidae } & Dasyatis centroura & & & & 5 & \\
\hline & Dasyatis pastinaca & & & & 2 & \\
\hline Myliobatidae & Myliobatis aquila & & & & 7 & \\
\hline
\end{tabular}

Except in the case of HTS, whose data contained global commercial categories before the 2000s (see Table 1), data were analysed separately for the continental shelf and slope elasmobranch communities. This was possible for the BTS data, since sample depth was recorded, and also for the DSB data using the methodology for classifying fishing tactics developed in a previous work (Palmer et al. 2009). It should be noted that species included in each commercial category can change over time (Morey and Navarro 2010), and in the case of HTS only three commercial categories were reflected, although they probably included other species.

For each series, the elasmobranch catch composition was obtained at different taxonomic levels depending on the data source: commercial categories in the HTS and DSB and species-specific in the BTS. The percentages of each category/species in relation to the total elasmobranch biomass were calculated.

Temporal trends in the different community variables reported in the three data sources were analysed using General Additive Models (GAMs; Hastie and Tibshirani 1990), which allow density-dependent and density-independent effects in population dynamics to be analysed (e.g. Ciannelli et al. 2004, Chen et al. 2005, Massutí et al. 2008). GAMs were implemented in the $\mathrm{R}$ package, using variations of GAM formulations, as implemented in the mgcv library (Wood 2004). The model selection criterion was based on minimising the generalized cross validation (GCV); low values indicated the best compromise between model complexities (e.g. number of parameters) and observed data. In the GAMs, the different response variables (abundance indices, $\mathrm{S}, \mathrm{H}^{\prime}$ and MFW) were analysed using both year (in all models) and month (in the HTS and DSB) as explanatory variables. When it was not possible to fit a significant model using GAMs, analysis of variance (ANOVA) was applied to test temporal variations in the descriptive variables.

Finally, the temporal trends for all the above mentioned variables were summarised using the Traffic Light procedure (Caddy 1999, 2002, Koeller et al. 2000). TL is a system of red, yellow and green colours that categorize multiple indicators of the state of a fishery or ecosystem. Red is considered to be bad, yellow as intermediate and green as good. A number of options are available for establishing boundaries for TL, such as Limit Reference Points, a percentage of the average value or the $33^{\text {rd }}$ and $66^{\text {th }}$ percentiles (Halliday et al. 2001). We applied this last option. A mean value for each of the indicators was calculated by year and a different colour was assigned if this value was under the $33^{\text {rd }}$ percentile (red, bad state), between the $33^{\text {rd }}$ and $66^{\text {th }}$ percentile (yellow, intermediate state) or over the $66^{\text {th }}$ percentile (green, good state).

\section{RESULTS}

Considering all three available data sources, it was determined that there is a total of 25 elasmobranch species in the fishing grounds of the Balearic Islands (Table 1). In the commercial catches, the predominant species were Galeus melastomus, Scyliorhinus canicula and Raja clavata, both for the long (HTS) and short (DSB) time series. However, data from the DSB, together with data from BTS, showed clear bathymetric differences, with a predominance of $S$. canicula and $R$. clavata over the shelf and G. melastomus over the 

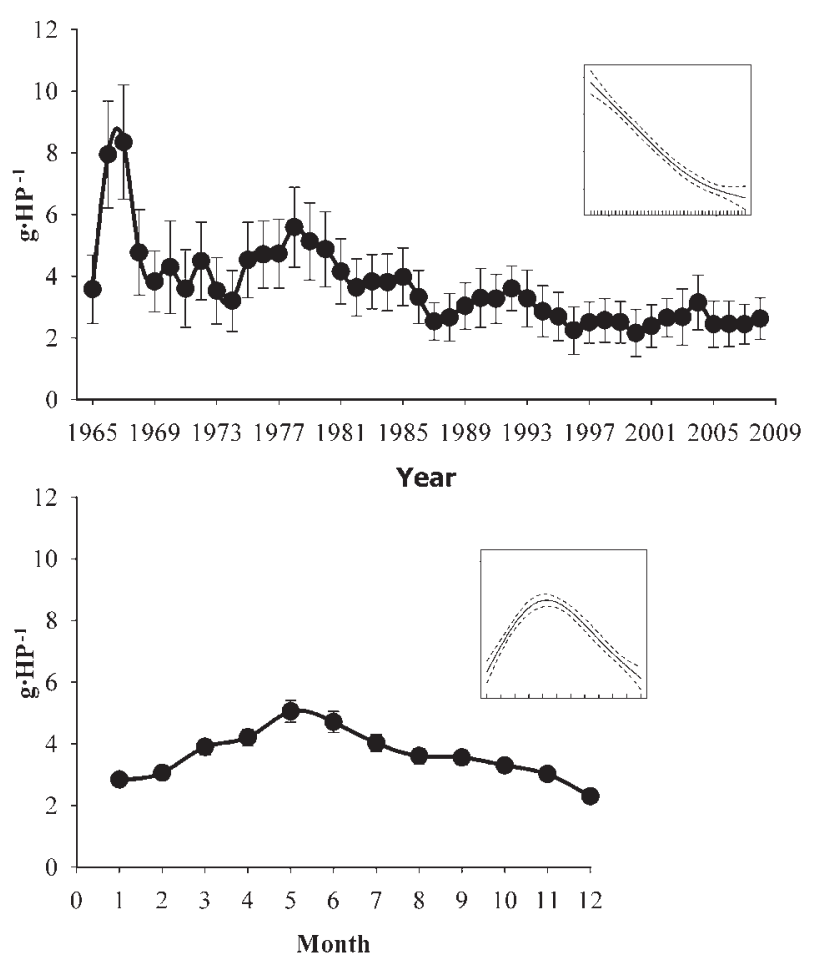

FIG. 2. - Mean annual (top) and seasonal (bottom) values of catches per unit effort $\left(\mathrm{g} \mathrm{HP}^{-1}\right)$ from the historical data series of elasmobranch landings and plots of the best significant generalized additive modelling (GAM) applied to this data (small graphs). Error bars indicate standard errors.
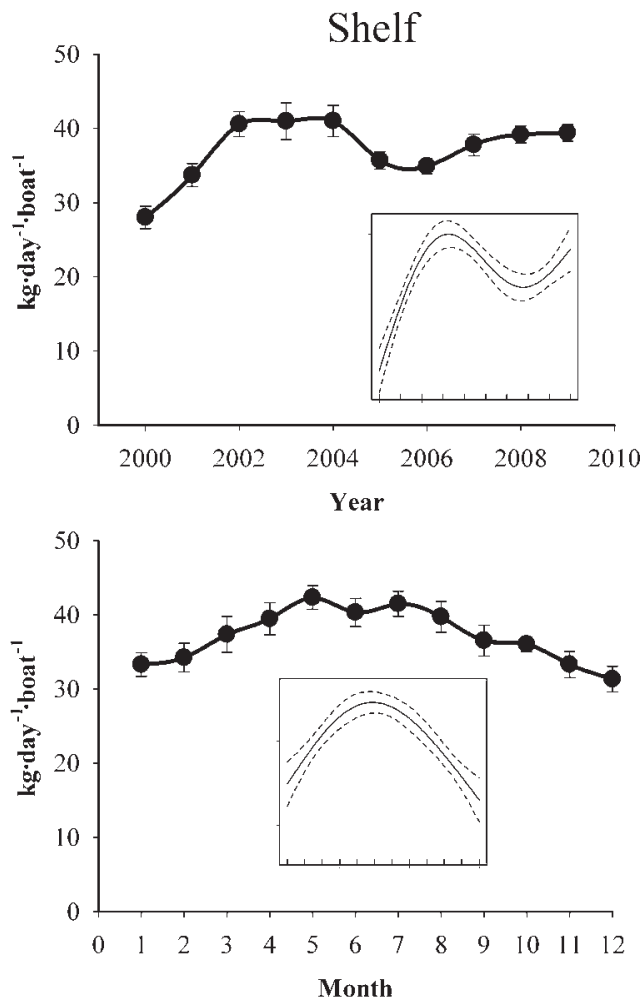

TABLE 2. - Results of generalized additive models (GAM) applied to the different variables analysed for the different data sets, showing the dependent variable, the explanatory variables, as well as the score, r-squared values $\left(\mathrm{R}^{2}\right)$ and deviance explained (DE). The significance of each explanatory variable $(* * *: \mathrm{p}<0.001,+\mathrm{p}<0.1 ; \mathrm{ns}$ : not significant or $\mathrm{p} \geq 0.1$ ) is also indicated. HTS: long term historical time series; DSB: daily sales records for the bottom trawl fleet; BTS: annual bottom trawl surveys. S: species richness; H': Shannon's diversity index; MFW: mean fish weight; NA: not available.

\begin{tabular}{|c|c|c|c|c|c|c|c|}
\hline & & & Year & Month & Score & $\mathrm{R}^{2}$ & $\mathrm{DE}(\%)$ \\
\hline HTS & & $\mathrm{g} \cdot \mathrm{HP}^{-1}$ & $* * *$ & $* * *$ & 1.616 & 0.48 & 48.5 \\
\hline \multirow[t]{2}{*}{ DSB } & Shelf & $\mathrm{kg}$ day $^{-1}$ boat $^{-1}$ & $* * *$ & $* * *$ & 0.01354 & 0.527 & 55.0 \\
\hline & Slope & $\mathrm{kg}$ day $^{-1}$ boat $^{-1}$ & ns & - & - & - & - \\
\hline \multirow[t]{10}{*}{ BTS } & Shelf & $\mathrm{kg} \mathrm{km}^{-2}$ & ns & NA & - & - & - \\
\hline & & $\mathrm{n} \mathrm{km}^{-2}$ & ns & NA & - & - & - \\
\hline & & $\mathrm{S}$ & $\mathrm{ns}$ & NA & - & - & - \\
\hline & & $\mathrm{H}^{\prime}$ & ns & NA & - & - & - \\
\hline & & MFW & + & NA & 52639 & 0.008 & 1.13 \\
\hline & Slope & $\mathrm{kg} \mathrm{km}^{-2}$ & ns & NA & - & - & - \\
\hline & & $\mathrm{n} \mathrm{km}^{-2}$ & ns & NA & - & - & - \\
\hline & & $\mathrm{S}$ & ns & NA & - & - & - \\
\hline & & $\mathrm{H}^{\prime}$ & ns & NA & - & - & - \\
\hline & & MFW & ns & NA & - & - & - \\
\hline
\end{tabular}

slope. The rest of the species represented low percentages of the biomass, several of them below $1 \%$.

Both the input variables and the results from the GAMs for each modelled parameter (abundance indices, S, H' and MFW) and data source (HTS, DSB and BTS) are presented in Table 2. The HTS showed a marked non-linear inter-annual decreasing trend throughout the years but also a clear seasonal trend,
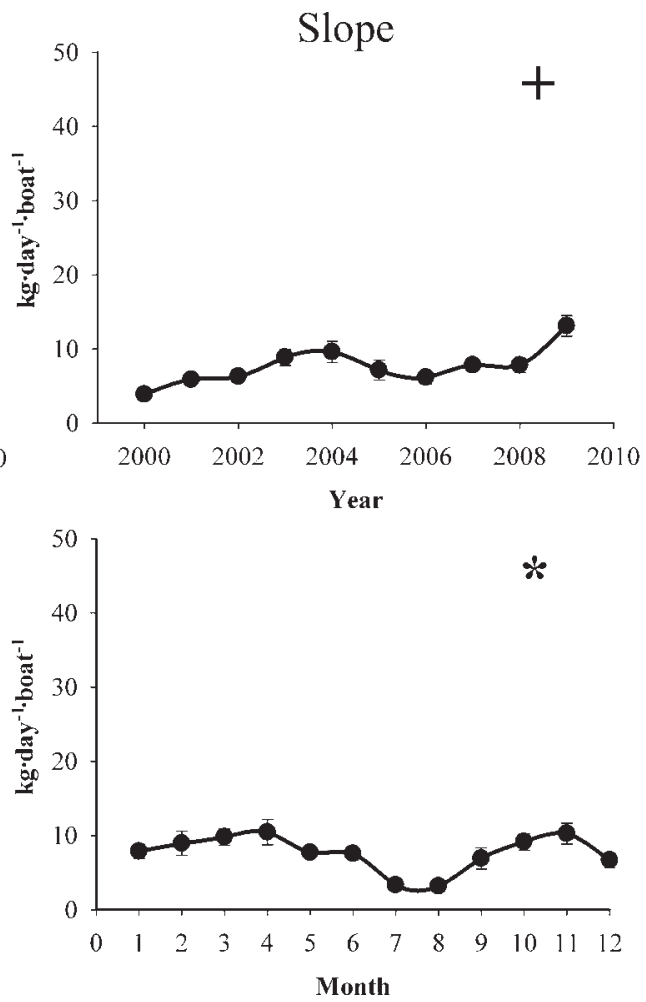

FIG. 3. - Mean annual (top) and seasonal (bottom) values of catches per unit effort $\left(\mathrm{kg} \mathrm{day}^{-1}\right.$ boat $^{-1}$ ) for the daily sales records of elasmobranch landings from the shelf and slope, plots of the best significant generalized additive modelling (GAM) applied to this data (small graphs) and results of the analysis of variance applied when no significant GAM model was found (*: $\mathrm{p}<0.05 ;+$ : $\mathrm{p}<0.1)$. Error bars indicate standard errors. 

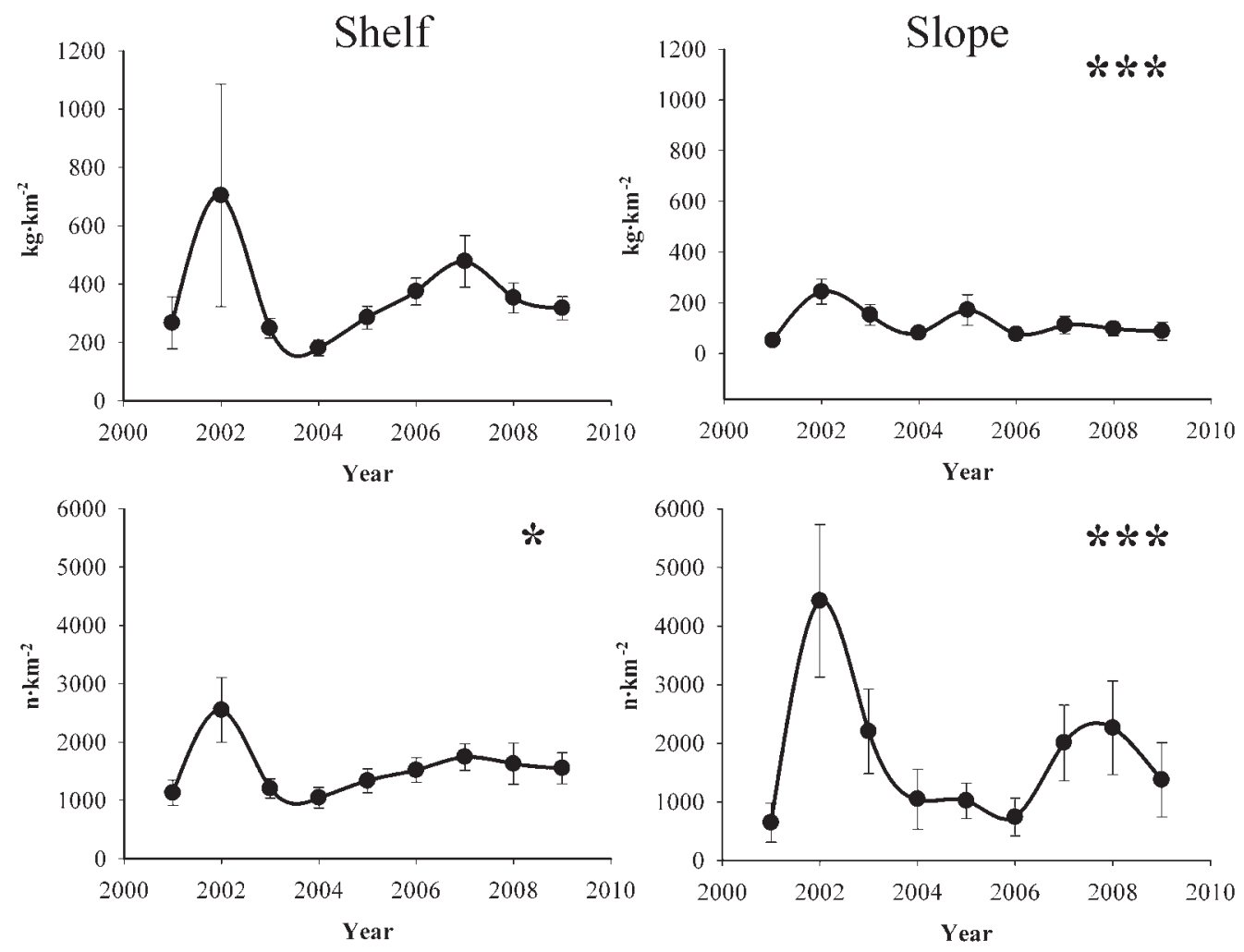

FIG. 4. - Mean values of catches per unit effort for the biomass $\left(\mathrm{kg} \mathrm{km}^{-2}\right.$, top) and abundance ( $\mathrm{n} \mathrm{km}^{-2}$, bottom) of elasmobranchs for the annual spring surveys from the shelf and slope and results of the analysis of variance $(* * *: p<0.001 ; *: p<0.05)$. Error bars indicate standard errors.

with CPUEs being highest during late spring-early summer (Fig. 2). The deviance explained by the GAM was nearly $50 \%$ and both year and month were highly significant.

Different results were found over the shelf and the slope with the DSB data (Fig. 3). In the first case, the GAM was significant both for year and month, with a bimodal distribution with maximum values in 2003 and 2009. Seasonal data agreed with the trend found using the HTS, with maximum values in late spring-summer. For the slope we could not fit a significant GAM model, but the ANOVA showed a marginally significant peak of elasmobranchs at the end of the data series (2009, $\left.\mathrm{F}_{1,9}=1.944, \mathrm{p}<0.1\right)$ and minimum values during summer $\left(\mathrm{F}_{1,11}=3.045, \mathrm{p}<0.05\right)$. For the BTS, GAMs were not significant for the biomass or the abundance, either on the shelf or the slope (Fig. 4). However, except for the biomass on the shelf, ANOVA showed significant maximum values at the beginning of the data series in all cases (biomass: $\mathrm{F}_{1,8}=2.893, \mathrm{p}<0.01$ on the slope; abundance: $2002 ; \mathrm{F}_{1,8}=2.075$, $\mathrm{p}<0.05$ and $\mathrm{F}_{1,8}=3.061$, $\mathrm{p}<0.01$, on the shelf and slope respectively). No significant trends were found for S and $\mathrm{H}^{\prime}$ on the shelf or the slope, but the GAMs showed a significant increase in MFW on the shelf and a marginally significant maximum in 2005 on the slope $\left(\mathrm{F}_{1,8}=1.992, \mathrm{p}<0.01\right)$ (Table 2, Fig. 5).

To summarize, all the results were displayed using the TL approach (Fig. 6). The HTS showed that the elasmobranch communities were in good condition from 1965 to the mid-1980s (green), but shifted to a bad condition during the mid-1990s (red) after a short period displaying an intermediate condition (yellow). The remaining data series (DSB and BTS) gave a closer insight into the 2000s, which showed differences between the shelf and slope results. Whereas no clear trends could be determined on the slope, since all three colours were heterogeneously distributed, the shelf data revealed a markedly better situation during the late 2000s than during the early 2000s for all ecological indicators.

\section{DISCUSSION}

This study used an approach based on multiple indicators to provide an initial description of the status of the demersal elasmobranch communities off the Balearic Islands. It is difficult to use traditional stock assessment methods for elasmobranchs due to the lack of accurate species-specific landings data and the paucity of biological data, which is partly because they are a common but unspecified bycatch in many fisheries, including demersal trawls, long-lines and gillnets (Stevens et al. 2000, Ellis et al. 2005). In fact, few countries have any form of management for these resources, and little baseline data have been collected because sharks have historically been of low economic value in most countries. Using the Traffic Light (TL) methodology 

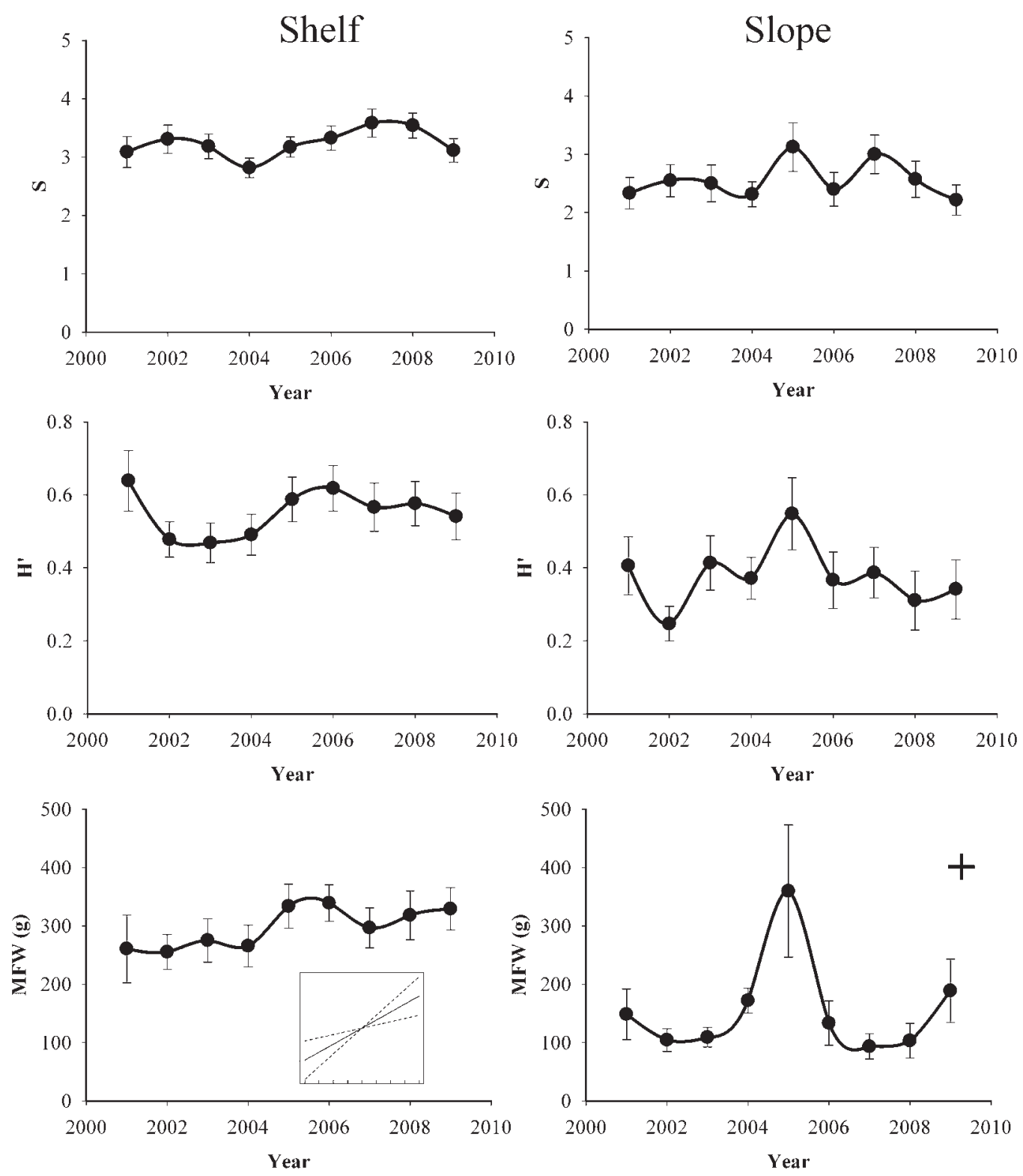

FIG. 5. - Mean values of species richness (S), diversity index (H') and mean fish weight (MFW) for the elasmobranchs caught in the annual spring surveys from the shelf and slope, plots of the best significant generalized additive modelling (GAM) applied to these data (small graphs) and results of the analysis of variance $(+: \mathrm{p}<0.01)$. Error bars indicate standard errors.

allowed us to determine changes that have occurred in the community and made it possible to assess the status of the population. Depicting indicator time series using TL provides a single framework for summarising results from different data sources, thus making them easy to understand as changes can be clearly seen.

Nevertheless, in some cases the multi-species indicators have revealed some difficulties in interpretation. When indicators are analysed at the community level, the different response of the more resilient species to the direct and indirect impacts of fishing could have compensated the decrease in the long-lived species, which makes the information provided by the multispecies indicators difficult to interpret (Ceriola et al.
2008). Ceriola et al. (2008) suggested that the lack of clear trends in the elasmobranch biomass index could be related to the high exploitation level in their study area (southern Adriatic Sea) that kept the elasmobranchs at a relatively low but steady level. This is not our case, because previous studies have considered the first part of the series as a period of under-exploitation for six analysed stocks (Quetglas, pers.comm.), including a category of elasmobranchs, mainly composed by $S$. canicula and $R$. clavata. Thus, in our study, the use of indicators for assessing the demersal elasmobranch communities off the Balearic Islands has shown a very clear decreasing trend from 1965 to 2009 . However, during the last years a slight improvement in the state 

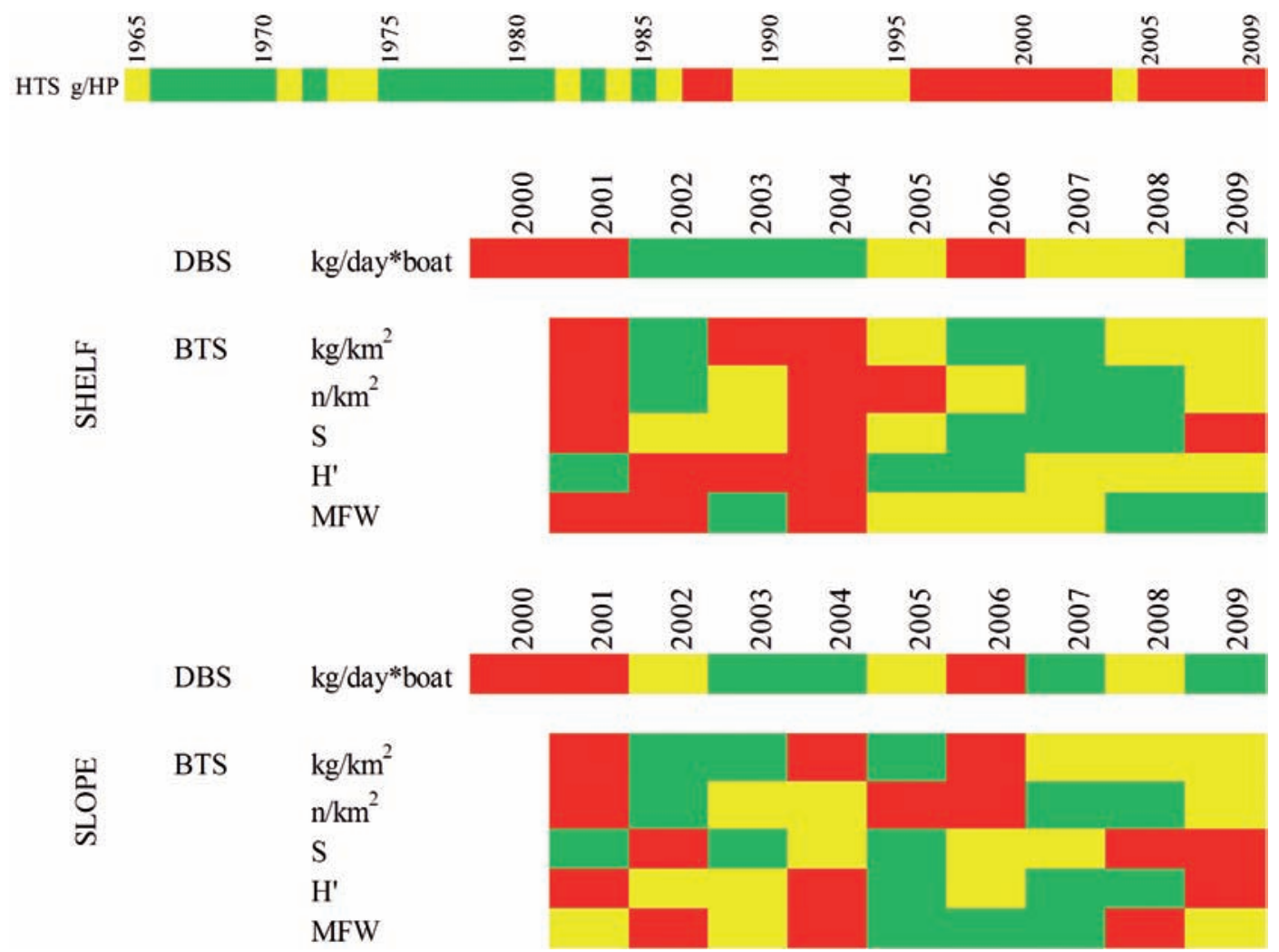

FIG. 6. - Traffic Light tables showing the response of elasmobranch indicators from the different data sources (HTS: long term historical time series; DSB: daily sales records from the bottom trawl fleet; BTS: annual bottom trawl surveys). S: species richness; H': diversity index; MFW: mean fish weight. For the grey scale version, white corresponds to green, grey to yellow and black to red.

of the community from the shelf has been detected, but there is no clear trend on the slope. Commercial fisheries are considered to be the biggest threat to elasmobranch species in the Mediterranean (Cavanagh and Gibson 2007) due to the vulnerability of these species related to their slow-growth, late attainment of sexual maturity, long life spans and low fecundity (Stevens et al. 2000). In fact, the proportion of threatened oceanic pelagic elasmobranchs is more than double that of all assessed chondrichthyans (Dulvy et al. 2008), and many demersal elasmobranchs have been severely depleted or their abundances decreased in some areas (e.g. Aldebert 1997, Bertrand et al. 1998, Casey and Myers 1998, Dulvy et al. 2000, Garofalo et al. 2003, Ellis et al. 2005). The diversity of demersal elasmobranchs in the Balearic Islands is higher than in adjacent waters off the Iberian Peninsula. This archipelago can be considered among the areas with the highest diversity in the Mediterranean, which has been related to a lower intensity in fishing exploitation (Massutí and Moranta 2003). The higher occurrence and abundance of threatened deep water sharks in nearby Algerian waters have been related to the fact that there is less deep water trawl fishing in this area compared to the Balearic Islands (Mouffok et al. 2008, Ordines et al. 2011). However, not all species are equally sensitive to the impact of fishing exploitation (Rogers et al. 1999), and large, late maturing species appear to be most vul- nerable (Stevens et al. 2000). For instance, Etmopterus spinax is considered to be extremely vulnerable to the fishing impact even within the general context of high elasmobranch vulnerability (Coelho and Erzini 2008). This species shows a clear decline in abundance in the red shrimp fishery of this area, which indicates that displacing the fishing effort to these bottoms could have begun to show its effect on the most vulnerable species (Ordines et al. 2011).

The fishing effort in the Balearic Islands increased between 1965 and 2008 (Quetglas, pers. comm.), but in different phases, increasing faster in the first period (1965-mid 1970s), then at a slower rate until 1994, at which point it gradually decreased. These authors demonstrated with a GAM that landings and effort (in HP) acted proportionally during the time series analysed (as in this study). This is a required property if the total effort has to be calculated for the entire fleet. During the last decades, a reduction in the bottom trawl fishing effort on the shelf bottoms of the archipelago has been detected and related to the displacement of this fishery towards greater depths (Moranta et al. 2008, Hidalgo et al. 2009), and also to the reinforcement (or extension) of some areas in the Balearic islands that are closed to trawling (e.g. areas with submarine cables, marine protected areas, agreements between fishers to avoid trawling in some areas of the shelf during summer). It is expected that these measures would have affected 
the elasmobranch communities positively (Ordines et al. 2011), at least over the shelf. This could explain the different trends found in the recent data for the shelf and slope; however, another explanation for this could be the different recovery capacities of the species. Once overfished, many shark populations would take several decades to recover (Stevens et al. 2000) and the benefits of management measures such as Marine Protected Areas for sharks and rays would be only detectable in the long-term (Morey et al. 2006). However, the ability to recover from exploitation depends on the life histories of the different species. Thus, sharks with the lowest recovery potential tend to be late-maturing medium to large-sized coastal sharks, whereas those with the highest potential are small coastal, early-maturing species (Smith et al. 1998). In this sense, the slight recovery observed in the elasmobranch community on the shelf, which has not been observed on the slope, could be related to differences in the recovery potential of the predominant species in each of the bathymetric assemblages.

Higher abundances of elasmobranchs have been detected during late spring and summer in the historical data series and on the shelf in the more recent data. However, a significant decrease in July-August was found on the slope. This lower values of catches per unit effort during summer on the slope could be related to an increase in the fishing effort during these months. because the bottom trawl fleet concentrates on the middle slope fishing grounds located in northwestern Mallorca during summer, targeting the large aggregations of mature females of the red shrimp Aristeus antennatus (Guijarro et al. 2008, Moranta et al. 2008). The biological characteristics of elasmobranchs seem to be related to their higher abundance during late spring and summer. In the study area, more elasmobranchs were caught with trammel nets in late spring and early summer, which is related to movement patterns in relation to reproductive behaviour, like mating related aggregations (Morey et al. 2006). In the eastern Mediterranean, seasonal patterns have been related to recruitment. Four benthic skates show higher relative densities during summer and autumn when young of the year specimens enter the fishery (Damalas et al. 2009) on the west Portuguese coast. The lowest values of species richness were recorded in spring and the highest values in autumn, which could be related to the reproductive or latitudinal migratory habits of these elasmobranch species (Baeta et al. 2010).

The relationship between environmental factors and elasmobranchs has been little studied. Walker (1998) pointed out that certain shark fisheries are advantageous as they can produce relatively stable yields which are less prone to interannual environmental effects compared to the fisheries of most teleost stocks. The heterogeneity of bottoms, their sediment type and the widespread occurrence of sensitive and essential fish habitats in the Balearic Islands (Ordines and Massutí 2009) are possible explanations for the higher values of abundance, biomass, species richness and diversity compared to the waters off the Algerian coast (Ordines et al. 2011). Biogeographic factors could be the basis of the above mentioned differences between the Balearic Islands and the Iberian Peninsula (Massutí and Moranta 2003). In fact, sediment type has a considerable effect on distribution and habitat selection of benthic Rajidae in the Mediterranean as they are closely related to the substrate (Damalas et al. 2009). The presence of relatively abundant stocks of Squalus acanthias and Squalus blainvillei in heavily exploited areas (i.e. S. acanthias in the northern Adriatic Sea or S. blainvillei in Sicily Straits) and their near absence in other areas with far lower fishing pressure (Tyrrhenian and Ionian Seas), suggests that other environmental factors may be determinant for the current distribution and abundance of these species in the Mediterranean (Serena et al. 2009).

This work was a first attempt at assessing the state of elasmobranch communities in the Balearic Islands; however, further studies need to be performed taking into account not only the role of fishing pressure but also the importance of environmental factors on the state of these vulnerable species. It is also important to carry out species-specific studies, as virtually nothing is known about the status of individual stocks and this is very useful information due to the different levels of vulnerability these species can show.

\section{ACKNOWLEDGEMENTS}

The authors wish to thank all the crew and the participants who took part in the BALAR and MEDITS surveys on board the R/V Francisco de Paula Navarro and Cornide de Saavedra respectively. These surveys were carried out in the framework of the MEDER, DEMO, EVADEM and EVADEMED projects, financed by the IEO and, from 2007, by the EU. The historical data series were collected within the project PROGECIB-48A, financed by the Government of the Balearic Islands.

\section{REFERENCES}

Aldebert Y. 1997. Demersal resources of the Gulf of Lions (Mediterranean). Impact on fish diversity. Vie Milieu 47: 275-284.

Baeta F., Batista M., Maia A., Costa M.J., Cabral H. 2010. Elasmobranch bycatch in a trammel net fishery in the Portuguese west coast. Fish. Res. 102(1-2): 123-129.

Bertrand J.A., Aldebert Y., Souplet A. 1998. Temporal variability of demersal species in the Gulf of Lions from trawl surveys (19831997). IFREMER Actes des Colloques 26: 153-164.

Bertrand J.A., Gil de Sola L., Papaconstantinou C., Relini G., Souplet A. 2000. Contribution on the distribution of elasmobranchs in the Mediterranean (from the MEDITS surveys). Biol. Mar. Medit. 7: 1-15.

Bertrand J.A., Gil de Sola L., Papaconstantinou C., Relini G., Souplet A. 2002. The general specifications of the MEDITS surveys. Sci. Mar. 66(Suppl. 2): 9-17.

Browman H.I., Stergiou K.I. 2004. Perspectives on ecosystembased approaches to the management of marine resources. Mar. Ecol. Prog. Ser. 274: 269-270.

Caddy J.F. 1998. A short review of precautionary reference points and some proposals for their use in data-poor situations. FAO 
Fisheries Technical Paper. No. 379, Rome, 30 pp.

Caddy J.F. 1999. Deciding on precautionary management measures for a stock based on a suite of Limit Reference Points (LRPs) as abasis for a multi-LRP harvest law. NAFO Sci. Council Stud. 32: 55-68.

Caddy J.F. 2002. Limit reference points, traffic lights, and holistic approaches to fisheries management with minimal stock assessment input. Fish. Res. 56(2): 133-137.

Caddy J.F., Wade E., Surette T., Hebert M., Moriyasu M. 2005. Using an empirical traffic light procedure for monitoring and forecasting in the Gulf of St. Lawrence fishery for the snow crab, Chionoecetes opilio. Fish. Res. 76(1): 123-145.

Capape C., Tomasini J.A., Quignard J.P. 2000. The Pleurotremate Elasmobranchs from the Languedoc coast (Southern France): biological and demographic observations. Vie Milieu 50(2): 123-133.

Carbonell A., Alemany F., Merella P., Quetglas A., Roman E. 2003. The by-catch of sharks in the western Mediterranean (Balearic Islands) trawl fishery. Fish. Res. 61(1-3): 7-18.

Casey J.M., Myers R.A. 1998. Near extinction of a large, widely distributed fish. Science 281(5377): 690-692.

Cavanagh R.D., Gibson C. 2007. Overview of the conservation status of cartilaginous fishes (Condrichthyans) in the Mediterranean Sea. IUCN, Gland, Switzerland and Málaga, Spain, 42 pp.

Ceriola L., Accadia P., Mannini P., Massa F., Milone N., Ungaro N. 2008. A bio-economic indicators suite for the appraisal of the demersal trawl fishery in the Southern Adriatic Sea (Central Mediterranean). Fish. Res. 92(2-3): 255-267.

Ceriola L., Ungaro N., Toteda F. 2007. A "Traffic" Light approach for the assessment of the Broadtail shortfin squid Illex coindetil Verany, 1839 in the Southern Adriatic Sea (Central Mediterranean). Rev. Fish Biol. Fish. 17(2-3): 145-157.

Chen Q.X., Chan K.S., Lekve K., Torstensen E., Gjosaeter J., Ottersen G., Stenseth N.C. 2005. Population dynamics of cod Gadus morhua in the North Sea region: biological densitydependent and climatic density-independent effects. Mar. Ecol. Prog. Ser. 302: 219-232.

Ciannelli L., Chan K.S., Bailey K.M., Stenseth N.C. 2004. Nonadditive effects of the environment on the survival of a large marine fish population. Ecology 85(12): 3418-3427.

Coelho R., Erzini K. 2008. Effects of fishing methods on deep water shark species caught as by-catch off southern Portugal. Hydrobiologia 606: 187-193.

Damalas D., Katsanevakis S., Maravelias C.D., Karageorgis A.P., Anagnostou C., Tsitsika E., Papaconstantinou C. 2009. Habitat preferences and spatiotemporal distribution of four benthic skates in the Eastern Mediterranean Sea. 9th Symposium on Oceanography and Fisheries - Proceedings, Volume II: 771-776.

DFO. 2005. Northern Shrimp on the Eastern Scotial Shelf (SFA 1315). DFO Can. Sci. Advis. Sec. Sci. Advis. Rep. 2005/060.

Dulvy N.K., Baum J.K., Clarke S., Compagno L.J.V., Cortes E., Domingo A., Fordham S., Fowler S., Francis M.P., Gibson C., Martinez J., Musick J.A., Soldo A., Stevens J.D., Valenti S. 2008. You can swim but you can't hide: the global status and conservation of oceanic pelagic sharks and rays. Aquat. Con serv. 18(5): 459-482.

Dulvy N.K., Metcalfe J.D., Glanville J., Pawson M.G., Reynolds J.D. 2000. Fishery stability, local extinctions, and shifts in community structure in skates. Conserv. Biol. 14(1): 283-293.

Ellis J., Dulvy N.K., Jennings S., Parker-Humphreys M., Rogers S.I. 2005. Assessing the status of demersal elasmobranchs in UK waters: a review. J. Mar. Biol. Ass. U.K. 85(5): 1025-1047.

Garofalo G., Gristina M., Fiorentino F., Fulgosi F.C., Norrito G., Sinacori G. 2003. Distributional pattern of rays (Pisces, Rajidae) in the Strait of Sicily in relation to fishing pressure. Hydrobiologia 503(1-3): 245-250.

Gouraguine A., Hidalgo M., Moranta J., Bailey D.M., Ordines F., Guijarro B., Valls M., Barberá C., Quetglas A., De Mesa A. 2011. Spatial segregation between deep water elasmobranch species related to biological and environmental factors. Sci. Mar., 75(4): 653-664.

Guijarro B., Massutí E. 2006. Selectivity of diamond- and squaremesh codends in the deepwater crustacean trawl fishery off the Balearic Islands (western Mediterranean). ICES J. Mar. Sci. 63(1): 52-67.

Guijarro B., Massutí E., Moranta J., Díaz P. 2008. Population dynamics of the red shrimp Aristeus antennatus in the Balearic
Islands (western Mediterranean): Short spatio-temporal differences and influence of environmental factors. J. Mar. Syst. 71: 385-402.

Guijarro B., Tserpes G., Moranta J., Massutí E. 2011. Assessment of the deep water trawl fishery off the Balearic Islands (western Mediterranean): from single to multi-species approach. Hydrobiologia, 670: 67-85.

Halliday R.G., Fanning L.P., Mohn R.K. 2001. Use of the Traffic Light Method in Fishery Management Planning. 2001/108 ISSN 1480-4883: 1-41

Hastie T.J., Tibshirani R.J. 1990. Generalized Additive Models. Chapman and Hall, New York, 335 pp.

Hidalgo M., Massutí E., Guijarro B., Moranta J., Ciannelli L., Lloret J., Oliver P., Stenseth N.C. 2009. Population effects and changes in life history traits in relation to phase transitions induced by long-term fishery harvesting: European hake (Merluccius merluccius) off the Balearic Islands. Can. J. Fish. Aquat. Sci. 66: $1355-1370$

Jennings S. 2005. Indicators to support an ecosystem approach to fisheries. Fish and Fisheries 6(3): 212-232.

Koeller P., Savard L., Parsons D.G., Fu C. 2000. A precautionary approach to assessment and management of shrimp stocks in the Northwest Atlantic. J. Northwest Atl. Fish. Soc. 27: 235-246.

Massutí E., Monserrat S., Oliver P., Moranta J., López-Jurado J.L., Marcos M., Hidalgo M., Guijarro B., Carbonell A., Pereda P. 2008. The influence of oceanographic scenarios on the population dynamics of demersal resources in the western Mediterranean: Hypothesis for hake and red shrimp off Balearic Islands. J. Mar. Syst. 71: 421-438.

Massutí E., Moranta J. 2003. Demersal assemblages and depth distribution of elasmobranchs from the continental shelf and slope off the Balearic Islands (western Mediterranean). ICES J. Mar. Sci. 60(4): 753-766.

Moranta J., Quetglas A., Massutí E., Guijarro B., Hidalgo M., Díaz P. 2008. Spatio-temporal variations in deep-sea demersal communities off the Balearic Islands (western Mediterranean). $J$. Mar. Syst. 71(3-4): 346-366.

Morey G., Moranta J., Riera F., Grau A.M., Morales-Nin B. 2006. Elasmobranchs in trammel net fishery associated to marine reserves in the Balearic Islands (NW Mediterranean). Cybium 30(4): $125-132$

Morey G., Navarro O. 2010. Monitoring of elasmobranchs landings in Mallorca (Balearic Islands, NW Mediterranean). Identification at species level and understanding of the official statistics. In: Book of abstracts of the 14th European Elasmobranch Association Conference. 10th-12th November 2010. Galway, Ireland.

Mouffok S., Massutí E., Boutiba Z., Guijarro B., Ordines F., Fliti K. 2008. Ecology and Fishery of the Deep-Water Shrimp, Aristeus Antennatus (Risso, 1816) Off Algeria (South-Western Mediterranean). Crustaceana 81(10): 1177-1199.

Ordines F., Massutí E. 2009. Relationships between macro-epibenthic communities and fish on the shelf grounds of the western Mediterranean. Aquat. Conserv. 19(4): 370-383.

Ordines F., Massutí E., Guijarro B., Mas R. 2006. Diamond vs square mesh codend in a multi-species trawl fishery of the western Mediterranean: effects on catch composition, yield, size selectivity and discards. Aquat. Living Resour. 19(4): 329-338.

Ordines F., Massutí E., Moranta J., Quetglas A., Guijarro B., Fliti K. 2011. Balearic Islands vs Algeria: two nearby western Mediterranean elasmobranchs populations with different oceanographic scenarios and fishing histories. Sci. Mar. 75(4): 707-717.

Palmer M., Quetglas A., Guijarro B., Moranta J., Ordines F., Massutí E. 2009. Performance of artificial neural networks and discriminant analysis in predicting fishing tactics from multispecific fisheries. Can. J. Earth Sci. 66(2): 224-237.

Relini G., Biagi F., Serena F., Belluscio A., Spedicato M.T., Rinelli P., Follesa M.C., Piccinetti C., Ungaro N., Sion L., Levi D. 2000. I Selaci pescati con lo strascico nei mari italiani. Biol. Mar. Medit. 7: 347-384.

Rochet M.J., Trenkel V.M. 2003. Which community indicators can measure the impact of fishing? A review and proposals. Can. J. Earth Sci. 60(1): 86-99.

Rogers S.I., Maxwell D., Rijnsdorp A.D., Damm U., Vanhee W. 1999. Fishing effects in northeast Atlantic shelf seas: patterns in fishing effort, diversity and community structure. IV. Can comparisons of species diversity be used to assess human impacts 
on demersal fish faunas? Fish. Res. 40(2): 135-152.

Serena F., Papaconstantinou C., Relini G., Gil de Sola L., Bertrand J.A. 2009. Distribution and abundance of spiny dogfish in the Mediterranean Sea based on the Mediterranean International Trawl Survey Program. In: Gallucci V.F., Mcfarlane G.A., Bargmann G.G. (eds.), Biology and management of Dogfish Sharks. American Fisheries Society, pp. 139-149.

Smith S.E., Au D.W., Show C. 1998. Intrinsic rebound potentials of 26 species of Pacific sharks. Mar. Freshw. Res. 49(7): 663-678.

Stevens J.D., Bonfil R., Dulvy N.K., Walker P.A. 2000. The effects of fishing on sharks, rays, and chimaeras (chondrichthyans), and the implications for marine ecosystems. ICES J. Mar. Sci. 57(3): 476-494.

Walker T.I. 1998. Can shark resources be harvested sustainably?
A question revisited with a review, of shark fisheries. Mar. Freshw. Res. 49(7): 553-572.

Wood S.N. 2004. Stable and efficient multiple smoothing parameter estimation for generalized additive models. J. Am. Stat. Ass. 99: 673-686.

Scient. ed.: D. Vaqué.

Guest ed.: G. Morey.

Received May 15, 2010. Accepted June 9, 2011.

Published online November 22, 2011.

This is a contribution to 13th European Elasmobranch Association Conference (Palma, 19-22 November 2009). 